\title{
Flashes of light and floaters: an unusual presentation of urothelial carcinoma
}

\author{
Satish Maharaj, ${ }_{1}^{1}$ Karan Seegobin, ${ }^{1}$ Marwan Shaikh, ${ }^{2}$ Fauzia Rana ${ }^{2}$
}

'Department of Internal Medicine, University of Florida College of Medicine, Jacksonville, Florida, USA ${ }^{2}$ Division of Hematology and Oncology, Department of Internal Medicine, University of Florida College of Medicine, Jacksonville, Florida, USA

\section{Correspondence to} Dr Satish Maharaj, satishsmaharaj@gmail.com

Accepted 15 August 2018

\section{Check for updates}

(C) BMJ Publishing Group Limited 2018. No commercial re-use. See rights and permissions. Published by BMJ.

\begin{tabular}{l}
\hline To cite: Maharaj S, \\
Seegobin K, Shaikh M, et al. \\
BMJ Case Rep Published \\
Online First: [please \\
include Day Month Year]. \\
doi:10.1136/bcr-2018- \\
225486 \\
\hline
\end{tabular}

\section{DESCRIPTION}

A 59-year-old Caucasian woman with multiple sclerosis presented with blurred vision in the right eye, floaters and flashes of light for 2 weeks. She had right-sided optic neuritis which was treated 8 years prior. There was a 20 pack-year smoking history. Examination was remarkable for right-sided temporal field loss and a palpable breast lump. Ophthalmological examination revealed right exudative retinal detachment, with ultrasonography demonstrating a choroidal mass with medium to high internal reflectivity. MRI was significant for a $14 \mathrm{~mm}$ intraocular metastasis (figure 1). On further questioning, the patient described haematuria. Urine cytology demonstrated large cells with high nuclear to cytoplasmic ratio, irregular nuclear borders and necrosis, all suggesting high-grade malignancy. Abdominal imaging revealed an ill-defined heterogeneously hypoenhancing infiltrative lesion of the right kidney within the mid and superior portions measuring $7.5 \times 6.6 \times 8.5 \mathrm{~cm}$ (figure 2). Biopsy of both the renal and breast masses confirmed urothelial carcinoma. Cells were immunoreactive for CK7, p63, GATA3 and uroplakin II and negative for CK20, PAX8, ER, PR and mammaglobin.

Choroidal metastasis is the most common form of uveal metastasis and is likely to be from breast or lung cancer in men and women, respectively. Intraocular metastasis from urothelial carcinoma is rarely seen while the patient is alive and usually detected on autopsy. ${ }^{1}$ Choroidal metastasis is extremely rare as the initial presentation of urothelial malignancy. ${ }^{23}$ If choroidal lesion is found, the use of fineneedle aspiration is controversial with some authors for, ${ }^{2}$ and others against. ${ }^{3}$ We agree with Cohen, ${ }^{4}$ that fine-needle aspiration should be reserved for

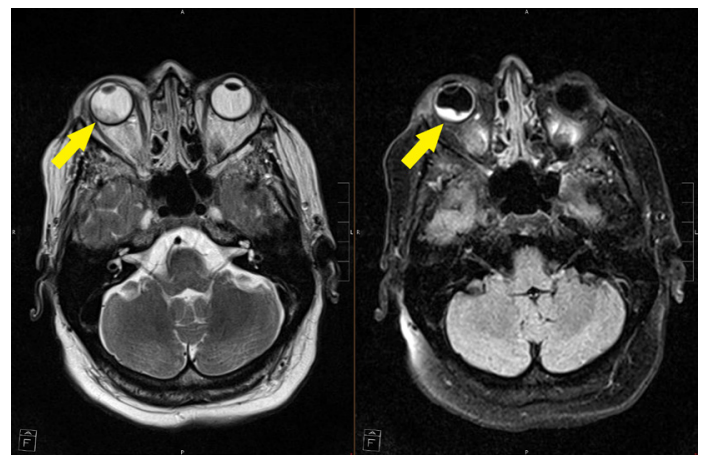

Figure 1 Axial MRI of the orbit, T2 (left) and fluid attenuated inversion recovery (FLAIR) sequences (right). The yellow arrow points to a right intraocular mass $(14 \mathrm{~mm})$ which is hypointense on $\mathrm{T} 2$ and hyperintense on FLAIR.

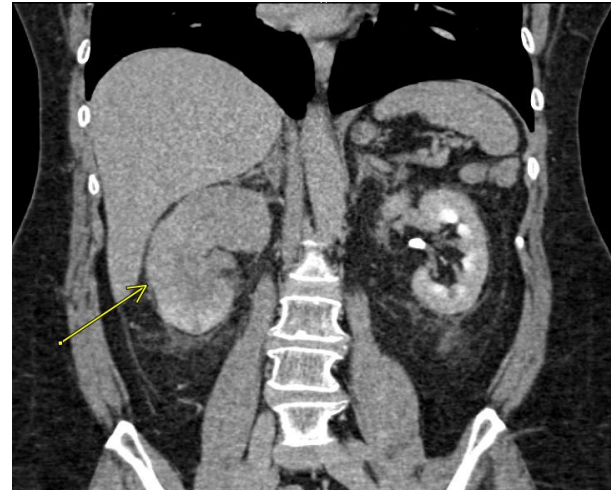

Figure 2 CT urogram showed an ill-defined heterogeneously infiltrating lesion of the right kidney within the mid and superior portions, $7.5 \times 6.6 \times 8.5 \mathrm{~cm}$ (yellow arrow). There is delayed right nephrogram and lack of excretion on delayed phase along with mild hydroureteronephrosis containing high-attenuation material, likely blood products.

cases of unidentified primary source and indeterminate diagnostic findings, after other modalities are exhausted and no primary cancer is discovered. The patient decided on hospice care with palliative radiotherapy and had improvement in pain but ultimately died, 5 months after presentation.

\section{Learning points}

- Choroidal metastasis presents as decreased visual acuity eventually progressing to retinal detachment. The patient will give a history of decreasing vision followed by flashers and floaters.

- Pre-existing eye disease is common with advancing age, however if the patient describes a history of haematuria, smoking, occupational exposure then further evaluation is warranted.

- If a choroidal lesion is found, the use of fine-needle aspiration is controversial, and a thorough search for a primary cancer should be undertaken.

Contributors SM, KS and MS provided clinical care for the patient and conceptualised the idea for the article. FR provided critical review and data analysis. All authors contributed to the manuscript. read and approved the final version.

Funding The authors have not declared a specific grant for this research from any funding agency in the public, commercial or not-for-profit sectors.

Competing interests None declared.

Patient consent Obtained. 
Provenance and peer review Not commissioned; externally peer reviewed.

\section{REFERENCES}

1 Bloch RS Gartner S. The incidence of ocular metastatic carcinoma. Arch Ophthalmol 1971;85:673-5.
2 Levecq L, De Potter P, Godfraind C, et al. Choroidal metastasis from carcinoma of the bladder. Retin Cases Brief Rep 2007;1:251-3.

3 Nabi G, Dadeya S, Dogra PN, et al. Eye metastasis form urothelial tumours. Int Urol Nephrol 2002:34:51-4.

4 Cohen VM. Ocular metastases. Eye 2013;27:137-41.

Copyright 2018 BMJ Publishing Group. All rights reserved. For permission to reuse any of this content visit http://group.bmj.com/group/rights-licensing/permissions.

BMJ Case Report Fellows may re-use this article for personal use and teaching without any further permission.

Become a Fellow of BMJ Case Reports today and you can:

- Submit as many cases as you like

- Enjoy fast sympathetic peer review and rapid publication of accepted articles

- Access all the published articles

- Re-use any of the published material for personal use and teaching without further permission

For information on Institutional Fellowships contact consortiasales@bmjgroup.com

Visit casereports.bmj.com for more articles like this and to become a Fellow 